\title{
Recent advances in understanding and managing secondary
}

\section{hyperparathyroidism in chronic kidney disease [version 1;}

\section{peer review: 3 approved]}

\author{
María E. Rodríguez-Ortiz (iD) 1-4, Mariano Rodríguez 1,2,4,5 \\ ${ }^{1}$ Maimónides Institute for Biomedical Research (IMIBIC), Avda. Menéndez Pidal, S/N. 14004 Córdoba, Spain \\ 2University of Córdoba, Avda. Medina Azahara, 5. 14071 Córdoba, Spain \\ 3University Hospital Reina Sofía, Avda. Menéndez Pidal, S/N. 14004 Córdoba, Spain \\ ${ }^{4}$ Spanish Renal Research Network (REDinREN), Carlos III Health Institute, Madrid, Spain \\ ${ }^{5}$ Nephrology Clinical Management Unit, University Hospital Reina Sofía, Avda. Menéndez Pidal, S/N. 14004 Córdoba, Spain
}

V1 First published: 01 Sep 2020, 9 (Faculty Rev):1077
https://doi.org/10.12688/f1000research.22636.1

https://doi.org/10.12688/f1000research.22636.1

https://doi.org/10.12688/f1000research.22636.1

\section{Abstract}

Secondary hyperparathyroidism is a complex pathology that develops as chronic kidney disease progresses. The retention of phosphorus and the reductions in calcium and vitamin $D$ levels stimulate the synthesis and secretion of parathyroid hormone as well as the proliferation rate of parathyroid cells. Parathyroid growth is initially diffuse but it becomes nodular as the disease progresses, making the gland less susceptible to be inhibited. Although the mechanisms underlying the pathophysiology of secondary hyperparathyroidism are well known, new evidence has shed light on unknown aspects of the deregulation of parathyroid function. Secondary hyperparathyroidism is an important feature of chronic kidney disease-mineral and bone disorder and plays an important role in the development of bone disease and vascular calcification. Thus, part of the management of chronic kidney disease relies on maintaining acceptable levels of mineral metabolism parameters in an attempt to slow down or prevent the development of secondary hyperparathyroidism. Here, we will also review the latest evidence regarding several aspects of the clinical and surgical management of secondary hyperparathyroidism.

\section{Keywords}

Chronic kidney disease-mineral and bone disorder, secondary hyperparathyroidism, calcimimetics, etelcalcetide, parathyroidectomy, chronic kidney disease, parathyroid, caSR, calcium

\section{Open Peer Review}

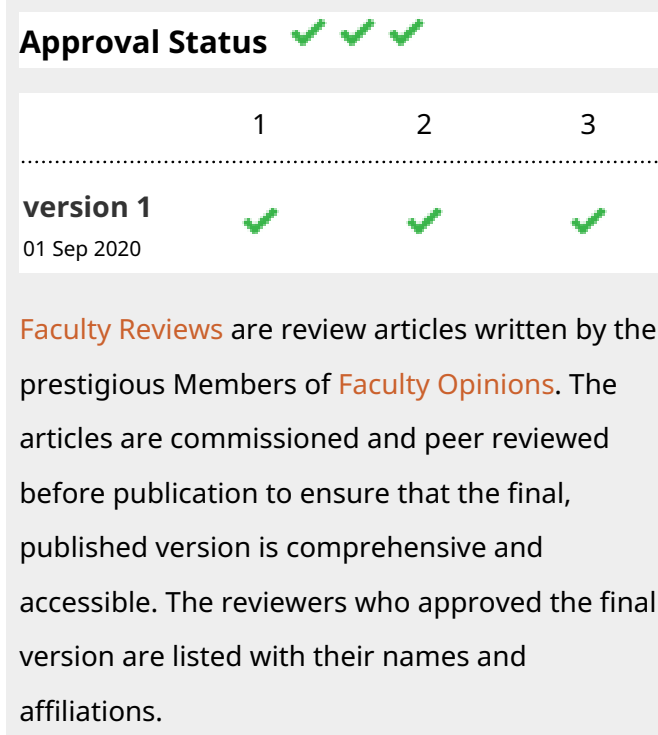

1. Tadao Akizawa, Showa University School of Medicine, Tokyo, Japan

2. Geoffrey A. Block, U.S. Renal Care, Plano, USA

Reata Pharmaceuticals, Dallas, USA

3. Masafumi Fukagawa, Tokai University

School of Medicine, Kanagawa, Japan

Any comments on the article can be found at the end of the article. 
Corresponding author: Mariano Rodríguez (marianorodriguezportillo@gmail.com)

Author roles: Rodríguez-Ortiz ME: Investigation, Writing - Original Draft Preparation, Writing - Review \& Editing; Rodríguez M: Conceptualization, Investigation, Writing - Original Draft Preparation, Writing - Review \& Editing

Competing interests: MR has received lecture fees from Amgen, Vifor Pharma, Kyowa Kirin, and Fresenius Medical Care. MR is member of the European Uremic Toxin (EUTox) Work Group and the Chronic Kidney Disease - Mineral Bone Disorder (CKD-MBD) Working Group. MER-O declares that she has no competing interests

Grant information: The author(s) declared that no grants were involved in supporting this work.

Copyright: $\odot 2020$ Rodríguez-Ortiz ME and Rodríguez M. This is an open access article distributed under the terms of the Creative Commons Attribution License, which permits unrestricted use, distribution, and reproduction in any medium, provided the original work is properly cited.

How to cite this article: Rodríguez-Ortiz ME and Rodríguez M. Recent advances in understanding and managing secondary hyperparathyroidism in chronic kidney disease [version 1; peer review: 3 approved] F1000Research 2020, 9(Faculty Rev):1077 https://doi.org/10.12688/f1000research.22636.1

First published: 01 Sep 2020, 9(Faculty Rev):1077 https://doi.org/10.12688/f1000research.22636.1 


\section{Introduction}

Mineral homeostasis is a tightly regulated process in which kidneys play an essential role. The development and progression of chronic kidney disease (CKD) cause serious disturbances in the maintenance of calcium $(\mathrm{Ca})$ and phosphorus $(\mathrm{P})$ metabolism. The term chronic kidney disease-mineral and bone disorder (CKD-MBD) summarizes all the alterations derived from the onset of $\mathrm{CKD}$ (that is, biochemical alterations, renal osteodystrophy, and extraosseous calcifications).

Parathyroid glands have a central role in mineral homeostasis. Under normal circumstances, small variations in serum $\mathrm{Ca}$ levels are detected by the Ca-sensing receptor (CaSR), located in the surface of parathyroid cells, which respond by secreting appropriate levels of parathyroid hormone (PTH). PTH stimulates bone resorption, releasing $\mathrm{Ca}$ and $\mathrm{P}$ ions into the extracellular space. At the renal level, PTH stimulates renal calcitriol $\left(1,25 \mathrm{D}_{3}\right)$ synthesis, which in turn promotes $\mathrm{Ca}$ and $\mathrm{P}$ absorption by the intestine. PTH, by stimulating tubular reabsorption, reduces renal excretion of $\mathrm{Ca}$ while exerting a phosphaturic action. All together, these actions are mainly intended to maintain appropriate concentrations of $\mathrm{Ca}$. The concentration of $\mathrm{P}$ is regulated predominantly by fibroblast growth factor 23 (FGF23), which reduces tubular reabsorption of $\mathrm{P}$. The parathyroid function is inhibited by high levels of $\mathrm{Ca}, 1,25 \mathrm{D}_{3}$, and FGF23. Derangements in the levels of these elements constitute potent stimuli for the onset and progression of secondary hyperparathyroidism (SHPT) $)^{1,2}$. Here, we will briefly review the latest advances regarding the pathophysiology and certain aspects of the management of SHPT.

\section{Novel insights into the pathogenesis of secondary hyperparathyroidism in patients with chronic kidney disease}

The development of SHPT occurs in response to the impairment of renal function, being frequently diagnosed at advanced stages of CKD. SHPT is characterized by elevated rates of PTH synthesis and secretion accompanied by parathyroid cell hyperplasia. Classically, three main factors present in CKD have been considered responsible for the onset and progression of SHPT: hypocalcemia, hyperphosphatemia, and low $1,25 \mathrm{D}_{3}$ levels. Nowadays, FGF23 is also recognized as an element that is intimately involved in the pathophysiology of SHPT ${ }^{3}$.

The aforementioned factors are responsible for the progression of hyperparathyroidism from diffuse to nodular by different mechanisms: hypocalcemia and hyperphosphatemia stimulates PTH production and secretion $^{4-6}$ and promotes cell proliferation. Hypocalcemia increases the expression of proliferating cell nuclear antigen ${ }^{7-9}$. The absent or reduced antiproliferative action of $1,25 \mathrm{D}_{3}{ }^{9}$ and the impaired regulation of $\mathrm{p} 21$ and $\alpha \mathrm{K}$ lotho/ FGFR signaling by FGF23 $3^{10,11}$ also contribute to the development of parathyroid hyperplasia. The progression from diffuse to nodular hyperplasia is characterized by a progressive reduction in the expression of parathyroid receptors. This is known as tertiary hyperparathyroidism and at this point the gland is refractory to the action of its natural inhibitors.

In early CKD, several factors contribute to the onset of SHPT. Since early CKD, there is an increase in the renal load of P. The increase in serum PTH and FGF23 prevents the accumulation of $\mathrm{P}$, but the excess of FGF23 reduces the serum concentration of $1,25 \mathrm{D}_{3}$, which results in a stimulus for $\mathrm{PTH}$ production. This effect is direct at the parathyroid level and indirect through the reduction in extracellular $\mathrm{Ca}$. The increase in the tubular load of $\mathrm{P}$ and the progressive reduction in the glomerular filtration rate cause a reduction in the renal expression of Klotho, which generates resistance to the action of FGF23 ${ }^{12}$. Thus, FGF23 production has to increase, $1,25 \mathrm{D}_{3}$ levels decrease further, and hyperparathyroidism is then established. With CKD stage 4 , the number of nephrons is reduced to the point that the increases in PTH and FGF23 are not able to augment $\mathrm{P}$ excretion and hyperphosphatemia, together with hypocalcemia, develops. In animals with normal renal function, the elevation in FGF23 causes a reduction in PTH production, but as parathyroid hyperplasia develops, there is a lower expression of parathyroid FGFR and Klotho receptors, which prevent any inhibitory effect of FGF $23^{10}$.

In patients on dialysis, hyperphosphatemia directly stimulates PTH secretion and maintains a persistent stimulus for parathyroid hyperplasia. Recent studies have demonstrated that high $\mathrm{P}$ prevents the activation of the $\mathrm{CaSR}^{13}$, a mechanism whereby $\mathrm{P}$ stimulates PTH secretion despite normal serum Ca levels. Another important effect of $\mathrm{P}$ is the generation of skeletal resistance to the calcemic effect of $\mathrm{PTH}^{14}$, which contributes to hypocalcemia with the subsequent stimulus for parathyroid hyperplasia. In the absence of kidney function, the production of $1,25 \mathrm{D}_{3}$ is very low and the consequences are hypocalcemia and parathyroid hyperplasia.

Although the mechanisms underlying the pathophysiology of SHPT are largely known, recent work has shed light on our knowledge of this pathology. Klotho serves as a co-receptor for FGF $23^{15}$. However, the use of genetic approaches has revealed that there is an interaction between Klotho and the CaSR and that Klotho has a key role in suppressing PTH synthesis and parathyroid proliferation ${ }^{16}$.

Several studies have shown that FGF23 suppresses PTH production by acting on the specific parathyroid receptor FGFR1 (FGF23 receptor 1)-Klotho. However, with the development of parathyroid hyperplasia, Klotho expression is reduced and the high FGF23 is not able to inhibit PTH production and parathyroid cell proliferation ${ }^{10,11}$. Clinical studies have demonstrated that FGF23 starts to rise at very early stages of CKD in an attempt to prevent accumulation of $\mathrm{P}$. The increase in FGF23 is observed before the elevation in $\mathrm{PTH}^{17}$. High FGF23 levels reduce the renal production of $1,25 \mathrm{D}_{3}$, which in turn promotes parathyroid hyperplasia. Phosphorus load, the main stimulus for FGF23 production, causes renal damage and a more rapid deterioration of renal function ${ }^{18}$ and $\mathrm{P}$ restriction prevents the elevation in FGF $23^{19-21}$. Thus, the early control of the factors influencing FGF23 also slows down the development of SHPT.

Although evidence of a direct stimulatory effect of P on PTH secretion was demonstrated more than 20 years ago, recent work by Centeno et al. ${ }^{13}$ shows that high $\mathrm{P}$ concentrations act on specific elements of the CaSR to stimulate PTH secretion. 
Therefore, it is very difficult to manage SHPT without controlling serum $\mathrm{P}$ levels. Furthermore, high serum $\mathrm{P}$ inhibits the calcemic response to PTH. Thus, in the presence of hyperphosphatemia, more PTH is required to maintain serum Ca levels ${ }^{14,22}$.

In regard to the signaling mechanisms involved in the development of parathyroid hyperplasia, a recent study by Kan et al. reported that vitamin $\mathrm{D}$ deficiency promotes activation of nuclear factor kappa $\mathrm{B}(\mathrm{NF \kappa B})$ both in parathyroid glands from patients on hemodialysis and in experimental models of uremia $^{23}$. Given that vitamin D also inhibits $\mathrm{NF \kappa B}$ in other tissues $^{24}$, this might represent an additional benefit of vitamin D supplementation in the management of SHPT.

It is widely known that hyperplastic glands are characterized by reduced expression of parathyroid vitamin D receptor (VDR), CaSR, and FGFR1 and its co-receptor Klotho. In this regard, a very interesting study has investigated the transcriptomic signature in hyperplastic parathyroid glands, performing comparative analyses with parathyroid adenomas and healthy tissue $^{25}$. In addition to the repeatedly reported down-regulation of the VDR and CaSR genes, marked reductions in NFIL3 and RET were found when hyperplastic and normal tissues were compared $^{25}$. In addition, there is increasing awareness about the involvement of microRNAs (miRNAs) in the pathophysiology of parathyroid hyperplasia. miRNAs are small non-coding RNA molecules that modulate the expression of RNA. The miRNA profile in healthy and pathological parathyroid tissue is not well known. This matter was deeply investigated by Shilo et al., who found high expression of members of let-7, miR-30, and miR-141/200 miRNA families in parathyroid samples from humans, mice, and rats ${ }^{26}$. In experimental hyperparathyroidism, the authors reported up-regulation of miR-29, miR-21, miR-148, miR-30, and miR-141 and down-regulation of miR-10, miR-125, and miR-25 ${ }^{26}$. Taken together, these results may help unravel novel mechanisms underlying the development of SHPT as well as design strategies to prevent parathyroid hyperplasia and manage PTH secretion.

\section{Recent advances in the management of secondary hyperparathyroidism}

\section{Novel calcimimetic agents}

Hyperparathyroidism is associated with poor outcomes in $\mathrm{CKD}^{27}$. According to the latest update of the Kidney Disease: Improving Global Outcomes (KDIGO) Guidelines on CKD-MBD, the optimal level of PTH for patients with CKD G3a-G5 not on dialysis is not known, and patients with intact PTH levels above the upper normal limit for the assay should be evaluated for factors such as hyperphosphatemia, hypocalcemia, high $\mathrm{P}$ intake, and vitamin $\mathrm{D}$ deficiency. In patients with CKD G5D requiring PTH-lowering therapy, calcimimetics, calcitriol, vitamin D analogs, or a combination of calcimimetics with calcitriol or vitamin $\mathrm{D}$ analogs is suggested ${ }^{28}$.

The identification and cloning of the $\mathrm{CaSR}^{29}$ allowed the development of calcimimetics, molecules that mimic $\mathrm{Ca}$ and therefore are able to modulate PTH secretion. Cinacalcet, effective in reducing PTH levels in patients on dialysis, was the first calcimimetic to be authorized for clinical use in patients on dialysis ${ }^{30,31}$. In preclinical experimental models, calcimimetics have also proven effective in preventing the development of vascular calcifications and even accelerating the regression of established calcifications in preclinical experimental models ${ }^{32,33}$. In humans, results from the ADVANCE study suggested that cinacalcet may attenuate vascular calcification in hemodialysis patients with moderate to severe SHPT $^{34}$. The EVOLVE trial was carried out to test the effectiveness of cinacalcet alone in reducing the risk of death or major cardiovascular events in patients undergoing dialysis, but no conclusive results were obtained ${ }^{35}$. Secondary analyses of the EVOLVE study disclosed that cinacalcet significantly reduced FGF23 levels and that this reduction was associated with lower rates of cardiovascular death and major cardiovascular events ${ }^{36}$. It has been described that cinacalcet increases bone mineral density when administered to patients on hemodialysis ${ }^{37}$. A very recent work revealed that this effect occurs independently of changes in PTH levels ${ }^{38}$.

Etelcalcetide (AMG416), a D-amino acid peptide, is a new calcimimetic recently approved in Europe and the United States for the treatment of SHPT in patients on hemodialysis. Unlike $\mathrm{Ca}$ and cinacalcet, etelcalcetide activates the CaSR by binding the extracellular domain ${ }^{39}$. Etelcalcetide ensures better compliance $^{40}$ and lower pill burden than cinacalcet since it is administered at the end of the hemodialysis session. The initial recommended dose is $5 \mathrm{mg}$ etelcalcetide three times a week, and the individual titration is according to the routine measurement of serum PTH and Ca levels and this represents another advantage of the use of this novel molecule.

In a phase I study, single doses of $0.5,2,5$, and $10 \mathrm{mg}$ etelcalcetide were administered to healthy volunteers, inducing rapid, dose-dependent reductions in iPTH (at $30 \mathrm{~min}$ ), ionized $\mathrm{Ca}$ (at $12 \mathrm{~h}$ ), and iFGF23 (at $24 \mathrm{~h}$ ) and there were no gastrointestinal adverse reactions ${ }^{41}$. A subsequent study performed in patients on hemodialysis reported similar results $^{42}$.

A randomized, double-blind multicenter clinical trial recently compared the effectiveness of intravenous (IV) etelcalcetide versus oral placebo and oral cinacalcet versus IV placebo for 26 weeks in 683 hemodialysis patients with PTH levels above $500 \mathrm{pg} / \mathrm{mL}^{43}$. The initial doses of etelcalcetide and cinacalcet were $5 \mathrm{mg}$ three times a week and $30 \mathrm{mg}$ per day, respectively. The proportions of patients achieving more than 50\% reduction in serum PTH were $52.4 \%$ and $40.2 \%$ in the etelcalcetide and cinacalcet arms, respectively, disclosing that etelcalcetide was non-inferior to cinacalcet in reducing PTH at the time point evaluated ${ }^{43}$. The effectiveness of etelcalcetide in lowering PTH has been confirmed irrespectively of the severity of SHPT, and there were higher requirements of calcimimetic in the most severe cases of hyperparathyroidism ${ }^{44}$. Overall, the effectiveness of etelcalcetide in controlling SHPT has been repeatedly proven, and a number of studies yielded similar results ${ }^{45,46}$. Furthermore, results obtained from a post hoc analysis of an open-label study performed in patients undergoing hemodialysis revealed that 52 weeks of 
etelcalcetide therapy were associated with lower circulating FGF23 and improvements in the levels of bone turnover markers ${ }^{47}$.

According to a very recent work integrating data from two trials, the most frequently reported adverse events were those derived from changes in parameters of mineral metabolism (hypocalcemia, hypophosphatemia, and muscle spasm) ${ }^{48}$. Safety and efficacy were evaluated following 1 year of treatment; there were no additional undesirable effects, and suppression of serum PTH levels continued ${ }^{49}$

Evocalcet is a calcimimetic agent that was developed and approved in Japan for the treatment of SHPT in patients on dialysis. It was developed in pursuit of a molecule capable of effectively managing PTH levels while avoiding the undesirable gastrointestinal effects associated with the use of cinacalcet ${ }^{50}$. Several studies point out that, similarly to cinacalcet, evocalcet binds to the transmembrane domain of the $\mathrm{CaSR}^{51}$.

In a phase I study, the administration of single doses of 1 to $20 \mathrm{mg}$ of evocalcet produced dose-dependent changes in $\mathrm{PTH}, \mathrm{Ca}$, and P, and evocalcet had a better safety profile than cinacalcet $^{52}$. The effectiveness of evocalcet was confirmed in a population of 152 hemodialysis patients with SHPT. In that study, an initial dose of $1 \mathrm{mg}$ of evocalcet was considered appropriate for the management of SHPT $^{53}$. Evocalcet has also been tested in peritoneal dialysis patients, and the results were similar in terms of efficacy and safety ${ }^{54}$. Additional studies have examined the safety profile of evocalcet in patients with SHPT. The administration of either single ${ }^{55}$ or multiple ${ }^{56}$ doses of evocalcet effectively controlled PTH levels and was well tolerated by the patients. The long-term efficacy and safety of evocalcet have also been proven, and sustained control of PTH and low rate of gastrointestinal side effects were reported ${ }^{57}$.

More recently, additional benefits of evocalcet beyond the management of phosphocalcium metabolism have been evaluated. Evocalcet has been shown to prevent extraosseous mineral deposition in an adenine-induced rat CKD model. Furthermore, evocalcet-treated animals exhibited lower rates of parathyroid cell proliferation when compared with controls ${ }^{58}$.

In sum, these novel molecules constitute promising therapeutic tools for the clinical management of SHPT in terms of controlling the levels of PTH, Ca, P, or FGF23 as well as in safety and tolerability. However, additional clinical studies are needed to clarify the impact of these emerging molecules on the cardiovascular morbidity and mortality risks associated with the derangements in the levels of these elements.

\section{Parathyroidectomy}

Parathyroidectomy (PTx) is the surgical resection of the parathyroid glands and is considered in patients with hyperparathyroidism refractory to conservative medical therapy. Owing to the availability of new molecules for medical therapy, the indications for PTx could be reduced to the following: (1) hyperparathyroidism resistant to calcimimetic administration, (2) severe refractory hyperphosphatemia, (3) severe hyperparathyroidism in dialysis without response to medical treatment, (4) cases of calciphylaxis with PTH levels above $500 \mathrm{pg} / \mathrm{mL}$ that do not rapidly respond to calcimimetics, (5) complications derived from SHPT, and (6) primary hyperparathyroidism in patients with $\mathrm{CKD}^{59}$. There are different modalities of PTx: subtotal PTx, total PTx with autotransplantation, and total PTx without autografting. The choice of one or another technique will depend on the clinical characteristics of the patient and the availability of a surgeon with the skills needed to perform the procedure ${ }^{59}$.

The use of PTx in patients with CKD is associated with improvements in biochemical parameters of mineral and bone metabolism ${ }^{60-62}$, cardiovascular health ${ }^{63}$, and mortality ${ }^{64,65}$. However, this technique is not free of complications, such as persistent hyperparathyroidism, often due to the existence of supernumerary or abnormally located parathyroid glands ${ }^{66}$, or the development of hungry bone syndrome due to PTH oversuppression $^{67}$.

The surgical removal of parathyroid glands is a useful resource mainly in cases of hyperparathyroidism refractory to medical treatment. However, it should be taken into account that, despite the post-surgical benefits, PTx is not free of complications, and the risks and benefits should be considered in each particular case.

\section{Conclusions}

The management of SHPT is essential to control CKD-MBD. Thus, the appropriate prevention and treatment of SHPT may derive in lower occurrence of metabolic bone disease, vascular calcifications, and mortality. The management of SHPT is based on avoiding hyperphosphatemia and decreasing PTH levels by administrating calcimimetics and, when needed, VDR activators. PTx is required in only a small proportion of patients.
1. Cunningham J, Locatelli F, Rodriguez M: Secondary hyperparathyroidism: Pathogenesis, disease progression, and therapeutic options. Clin J Am So Nephrol. 2011; 6(4): 913-21.

PubMed Abstract | Publisher Full Text
2. Portillo MR, Rodríguez-Ortiz ME: Secondary Hyperparthyroidism: Pathogenesis, Diagnosis, Preventive and Therapeutic Strategies. Rev Endocr Metab Disord. 2017: 18(1): 79-95.

PubMed Abstract | Publisher Full Text 
3. Silver J, Naveh-Many T: FGF-23 and secondary hyperparathyroidism in chronic kidney disease. Nat Rev Nephrol. 2013; 9(11): 641-9.

PubMed Abstract | Publisher Full Text

4. Almaden $Y$, Canalejo A, Hernandez A, et al.: Direct effect of phosphorus on PTH secretion from whole rat parathyroid glands in vitro. J Bone Miner Res. 1996; 11(7): 970-6.

PubMed Abstract | Publisher Full Text

5. Nielsen PK, Feldt-Rasmussen U, Olgaard K: A direct effect in vitro of phosphate on PTH release from bovine parathyroid tissue slices but not from dispersed parathyroid cells. Nephrol Dial Transplant. 1996; 11(9): 1762-8. PubMed Abstract

6. Slatopolsky E, Finch J, Denda M, et al.: Phosphorus restriction prevents parathyroid gland growth. High phosphorus directly stimulates PTH secretion in vitro. J Clin Invest. 1996; 97(11): 2534-40.

PubMed Abstract | Publisher Full Text | Free Full Text

7. Naveh-Many $T$, Rahamimov R, Livni $\mathrm{N}$, et al.: Parathyroid cell proliferation in normal and chronic renal failure rats. The effects of calcium, phosphate, and vitamin D. J Clin Invest. 1995; 96(4): 1786-93.

PubMed Abstract | Publisher Full Text | Free Full Text

8. Canalejo A, Hernández A, Almadén $Y$, et al.: The effect of a high phosphorus diet on the parathyroid cell cycle. Nephrol Dial Transplant. 1998; 13 Suppl 3: 19-22.

PubMed Abstract | Publisher Full Text

9. Almaden $\mathrm{Y}$, Felsenfeld AJ, Rodriguez $\mathrm{M}$, et al.: Proliferation in hyperplastic human and normal rat parathyroid glands: Role of phosphate, calcitriol, and gender. Kidney Int. 2003; 64(6): 2311-7.

PubMed Abstract | Publisher Full Text

10. Canalejo R, Canalejo A, Martinez-Moreno JM, et al.: FGF23 Fails to Inhibit Uremic Parathyroid Glands. J Am Soc Nephrol. 2010; 21(7): 1125-35.

PubMed Abstract | Publisher Full Text | Free Full Text |

Faculty Opinions Recommendation

11. Kawakami K, Takeshita A, Furushima K, et al.: Persistent fibroblast growth factor $\mathbf{2 3}$ signalling in the parathyroid glands for secondary hyperparathyroidism in mice with chronic kidney disease. Sci Rep. 2017; 7: 40534.

PubMed Abstract | Publisher Full Text | Free Full Text

12. Muñoz-Castañeda JR, Herencia C, Pendón-Ruiz de Mier MV, et al.: Differential regulation of renal Klotho and FGFR1 in normal and uremic rats. FASEB J. 2017; 31(9): 3858-67.

PubMed Abstract | Publisher Full Text

13. Centeno PP, Herberger A, Mun HC, et al: Phosphate acts directly on the calcium-sensing receptor to stimulate parathyroid hormone secretion. Nat Commun 2019: 10(1): 4693.

PubMed Abstract | Publisher Full Text | Free Full Text

Faculty Opinions Recommendation

14. Rodriguez M, Martin-Malo A, Martinez ME, et al:: Calcemic response to parathyroid hormone in renal failure: Role of phosphorus and its effect on calcitriol. Kidney Int. 1991; 40(6): 1055-62.

PubMed Abstract | Publisher Full Text

15. U Urakawa I, Yamazaki Y, Shimada T, et al.: Klotho converts canonical FG receptor into a specific receptor for FGF23. Nature. 2006; 444(7120): 770-4. PubMed Abstract | Publisher Full Text | Faculty Opinions Recommendation

16. Fan Y, Liu W, Bi R, et al.: Interrelated role of Klotho and calcium-sensing receptor in parathyroid hormone synthesis and parathyroid hyperplasia. Proc Natl Acad Sci U S A. 2018; 115(16): E3749-E3758.

PubMed Abstract | Publisher Full Text | Free Full Text |

Faculty Opinions Recommendation

17. N Isakova T, Wahl P, Vargas GS, et al.: Fibroblast growth factor 23 is elevated before parathyroid hormone and phosphate in chronic kidney disease. Kidney Int. 2011; 79(12): 1370-8.

PubMed Abstract | Publisher Full Text | Free Full Text Faculty Opinions Recommendation

18. Santamaría R, Díaz-Tocados JM, Pendón-Ruiz de Mier MV, et al.: Increased Phosphaturia Accelerates The Decline in Renal Function: A Search for Mechanisms. Sci Rep. 2018; 8(1): 13701. PubMed Abstract | Publisher Full Text | Free Full Text

19. Soriano $\mathrm{S}$, Ojeda R, Rodríguez $\mathrm{M}$, et al.: The effect of phosphate binders, calcium and lanthanum carbonate on FGF23 levels in chronic kidney disease patients. Clin Nephrol. 2013; 80(1): 17-22. PubMed Abstract | Publisher Full Text

20. Gonzalez-Parra E, Gonzalez-Casaus ML, Galán A, et al: Lanthanum carbonate reduces FGF23 in chronic kidney disease Stage 3 patients. Nephrol Dial Transplant. 2011; 26(8): 2567-71 PubMed Abstract | Publisher Full Text

21. Rodríguez-Ortiz ME, Díaz-Tocados JM, Muñoz-Castañeda JR, et al: Inflammation both increases and causes resistance to FGF23 in normal and uremic rats. Clin Sci (Lond). 2020; 134(1): 15-32. PubMed Abstract | Publisher Full Text

22. Rodriguez $\mathrm{M}$, Felsenfeld $\mathrm{A}$, Llach F: Calcemic response to parathyroid hormone in renal failure: Role of calcitriol and the effect of parathyroidectomy. Kidney Int. 1991; 40(6): 1063-8. PubMed Abstract | Publisher Full Text
23. Kan S, Zhang W, Mao J, et al.: NF-KB activation contributes to parathyroid cell proliferation in chronic kidney disease. J Nephrol. 2018; 31(6): 941-51. PubMed Abstract | Publisher Full Text | Faculty Opinions Recommendation

24. Tan X, Wen X, Liu Y: Paricalcitol Inhibits Renal Inflammation by Promoting Vitamin D Receptor-Mediated Sequestration of NF-KB Signaling. J Am Soc Nephrol. 2008; 19: 1741-52.

PubMed Abstract | Publisher Full Text | Free Full Text

25. N Sadowski SM, Pusztaszeri M, Brulhart-Meynet MC, et al.: Identification of Differential Transcriptional Patterns in Primary and Secondary Hyperparathyroidism. J Clin Endocrinol Metab. 2018; 103(6): 2189-98. PubMed Abstract | Publisher Full Text | Faculty Opinions Recommendation

26. Shilo V, Mor-Yosef Levi I, Abel R, et al.: Let-7 and MicroRNA-148 Regulate Parathyroid Hormone Levels in Secondary Hyperparathyroidism. J Am SoC Nephrol. 2017; 28(8): 2353-63.

PubMed Abstract | Publisher Full Text | Free Full Text

27. Block GA, Klassen PS, Lazarus JM, et al.: Mineral metabolism, mortality, and morbidity in maintenance hemodialysis. J Am Soc Nephrol. 2004; 15(8): 2208-18.

PubMed Abstract | Publisher Full Text

28. Kidney Disease: Improving Global Outcomes (KDIGO) CKD-MBD Update Work Group: KDIGO 2017 Clinical Practice Guideline Update for the Diagnosis, Evaluation, Prevention, and Treatment of Chronic Kidney Disease-Minera and Bone Disorder (CKD-MBD). Kidney Int Suppl (2011). 2017; 7(1): 1-59. PubMed Abstract | Publisher Full Text | Free Full Text

29. Brown EM, Gamba G, Riccardi D, et al.: Cloning and characterization of an extracellular $\mathrm{Ca}(2+)$-sensing receptor from bovine parathyroid. Nature. 1993: 366(6455): 575-80.

PubMed Abstract | Publisher Full Text

30. Block GA, Martin KJ, de Francisco ALM, et al:: Cinacalcet for Secondary Hyperparathyroidism in Patients Receiving Hemodialysis. N EnglJ Med. 2004; 350(15): 1516-25. PubMed Abstract | Publisher Full Text

31. Lindberg JS, Culleton B, Wong G, et al:: Cinacalcet $\mathbf{H C l}$, an oral calcimimetic agent for the treatment of secondary hyperparathyroidism in hemodialysis and peritoneal dialysis: a randomized, double-blind, multicenter study. J Am Soc Nephrol. 2005; 16(3): 800-7. PubMed Abstract | Publisher Full Text

32. Lopez I, Aguilera-Tejero E, Mendoza FJ, et al:: Calcimimetic R-568 Decreases Extraosseous Calcifications in Uremic Rats Treated with Calcitriol. J Am Soc Nephrol. 2006; 17(3): 795-804. PubMed Abstract | Publisher Full Text

33. Lopez I, Mendoza FJ, Guerrero F, et al.: The calcimimetic AMG 641 accelerates regression of extraosseous calcification in uremic rats. Am J Physiol Renal Physiol. 2009; 296(6): F1376-85.

PubMed Abstract | Publisher Full Text

34. Raggi P, Chertow GM, Torres PU, et al:: The ADVANCE study: A randomized study to evaluate the effects of cinacalcet plus low-dose vitamin $D$ on vascular calcification in patients on hemodialysis. Nephrol Dial Transplant. 2011; 26(4): 1327-39.

PubMed Abstract | Publisher Full Text | Faculty Opinions Recommendation

35. Chertow GM, Block GA, Correa-Rotter R, et al.: Effect of cinacalcet on cardiovascular disease in patients undergoing dialysis. N EnglJ Med. 2012 367(26): 2482-94

PubMed Abstract | Publisher Full Text | Faculty Opinions Recommendation

36. Moe SM, Chertow GM, Parfrey PS, et al:: Cinacalcet, Fibroblast Growth Factor-23, and Cardiovascular Disease in Hemodialysis: The Evaluation of Cinacalcet HCI Therapy to Lower Cardiovascular Events (EVOLVE) Trial. Circulation. 2015; 132(1): 27-39.

PubMed Abstract | Publisher Full Text

37. Tsuruta Y, Okano K, Kikuchi K, et al.: Effects of cinacalcet on bone mineral density and bone markers in hemodialysis patients with secondary hyperparathyroidism. Clin Exp Nephrol. 2013; 17(1): 120-6. PubMed Abstract | Publisher Full Text

38. Díaz-Tocados JM, Rodríguez-Ortiz ME, Almadén Y, et al.: Calcimimetics maintain bone turnover in uremic rats despite the concomitant decrease in parathyroid hormone concentration. Kidney Int. 2019; 95(5): 1064-78. PubMed Abstract | Publisher Full Text

39. Alexander ST, Hunter T, Walter S, et al.: Critical Cysteine Residues in Both the Calcium-Sensing Receptor and the Allosteric Activator AMG 416 Underlie the Mechanism of Action. Mol Pharmacol. 2015; 88(5): 853-65. PubMed Abstract | Publisher Full Text

40. Arenas MD, Rodelo-Haad C, de Mier MVPR, et al: Control of hyperparathyroidism with the intravenous calcimimetic etelcalcetide in dialysis patients adherent and non-adherent to oral calcimimetics. Clinical Kidney Journal. 2020; 2: 323 Publisher Full Text

41. Martin KJ, Bell G, Pickthorn K, et al: Velcalcetide (AMG 416), a novel peptide agonist of the calcium-sensing receptor, reduces serum parathyroid hormone and FGF23 levels in healthy male subjects. Nephrol Dial Transplant. 2014; 29(2): 385-92 PubMed Abstract | Publisher Full Text | Free Full Text

42. Martin KJ, Pickthorn K, Huang S, et al.: AMG $\mathbf{4 1 6}$ (velcalcetide) is a novel peptide for the treatment of secondary hyperparathyroidism in a 
single-dose study in hemodialysis patients. Kidney Int. 2014; 85(1): 191-7. PubMed Abstract | Publisher Full Text

43. Block GA, Bushinsky DA, Cheng S, et al.: Effect of Etelcalcetide vs Cinacalcet on Serum Parathyroid Hormone in Patients Receiving Hemodialysis With Secondary Hyperparathyroidism: A Randomized Clinical Trial. JAMA. 2017; 317(2): 156-64.

PubMed Abstract | Publisher Full Text

44. Cunningham J, Block GA, Chertow GM, et al.: Etelcalcetide Is Effective at All Levels of Severity of Secondary Hyperparathyroidism in Hemodialysis Patients. Kidney Int Rep. 2019; 4(7): 987-94.

PubMed Abstract | Publisher Full Text | Free Full Text Faculty Opinions Recommendation

45. Shigematsu T, Fukagawa M, Yokoyama K, et al.: Long-term effects of etelcalcetide as intravenous calcimimetic therapy in hemodialysis patients with secondary hyperparathyroidism. Clin Exp Nephrol. 2018; 22(2): 426-36. PubMed Abstract | Publisher Full Text | Faculty Opinions Recommendation

46. Russo D, Tripepi R, Malberti F, et al.: Etelcalcetide in Patients on Hemodialysis with Severe Secondary Hyperparathyroidism. Multicenter Study in "Real Life". J Clin Med. 2019; 8(7): 1066.

PubMed Abstract | Publisher Full Text | Free Full Text | Faculty Opinions Recommendation

47. Shigematsu T, Fukagawa M, Yokoyama K, et al.: Effects of the Intravenous Calcimimetic Etelcalcetide on Bone Turnover and Serum Fibroblast Growth Factor 23: Post Hoc Analysis of an Open-label Study. Clin Ther. 2018; 40(12): 2099-111.

PubMed Abstract | Publisher Full Text | Faculty Opinions Recommendation

48. Block GA, Chertow GM, Sullivan JT, et al.: An integrated analysis of safety and tolerability of etelcalcetide in patients receiving hemodialysis with secondary hyperparathyroidism. PLoS One. 2019; 14(3): e0213774. PubMed Abstract | Publisher Full Text | Free Full Text Faculty Opinions Recommendation

49. Bushinsky DA, Chertow GM, Cheng S, et al.: One-year safety and efficacy of intravenous etelcalcetide in patients on hemodialysis with secondary hyperparathyroidism. Nephrol Dial Transplant. 2019; gfz039. PubMed Abstract | Publisher Full Text | Faculty Opinions Recommendation

50. Nawata T, Tokunaga S, Murai M, et al:: A novel calcimimetic agent, evocalcet (MT-4580/KHK7580), suppresses the parathyroid cell function with little effect on the gastrointestinal tract or CYP isozymes in vivo and in vitro. PLoS One. 2018; 13(4): e0195316. PubMed Abstract | Publisher Full Text | Free Full Text | Faculty Opinions Recommendation

51. Akizawa T, Ikejiri K, Kondo Y, et al.: Evocalcet: A New Oral Calcimimetic for Dialysis Patients With Secondary Hyperparathyroidism. Ther Apher Dial. 2019: 24(3): 248-257.

PubMed Abstract | Publisher Full Text | Free Full Text

Faculty Opinions Recommendation

52. Aakizawa T, Shimazaki R, Shiramoto M, et al.: Pharmacokinetics, Pharmacodynamics, and Safety of the Novel Calcimimetic Agent Evocalce in Healthy Japanese Subjects: First-in-Human Phase I Study. Clin Drug Investig. 2018; 38(10): 945-54.

PubMed Abstract | Publisher Full Text | Free Full Text | Faculty Opinions Recommendation

53. Nakizawa T, Shimazaki R, Fukagawa M: Phase 2b study of evocalcet (KHK7580), a novel calcimimetic, in Japanese patients with secondary hyperparathyroidism undergoing hemodialysis: A randomized, doubleblind, placebo-controlled, dose-finding study. PLOS One. 2018; 13(10): e0204896.

PubMed Abstract | Publisher Full Text | Free Full Text Faculty Opinions Recommendation

54. Tsuruya K, Shimazaki R, Fukagawa M, et al.: Efficacy and safety of evocalcet in Japanese peritoneal dialysis patients. Clin Exp Nephrol. 2019; 23(6): 739-48.

PubMed Abstract | Publisher Full Text | Free Full Text |

Faculty Opinions Recommendation

55. Shigematsu T, Shimazaki R, Fukagawa M, et al.: Pharmacokinetics of evocalce in secondary hyperparathyroidism patients receiving hemodialysis: Firstin-patient clinical trial in Japan. Clin Pharmacol. 2018; 10: 101-11. PubMed Abstract | Publisher Full Text | Free Full Text

56. Shigematsu T, Shimazaki R, Fukagawa M, et al.: Pharmacodynamics of evocalcet for secondary hyperparathyroidism in Japanese hemodialysis patients. Clin Exp Nephrol. 2019; 23(2): 258-67.

PubMed Abstract | Publisher Full Text | Free Full Text

57. Nyokoyama K, Shimazaki R, Fukagawa M, et al.: Long-Term Efficacy and Safety of Evocalcet in Japanese Patients with Secondary Hyperparathyroidism Receiving Hemodialysis. Sci Rep. 2019; 9(1): 6410. PubMed Abstract | Publisher Full Text | Free Full Text | Faculty Opinions Recommendation

58. Sakai M, Tokunaga S, Kawai M, et al.: Evocalcet prevents ectopic calcification and parathyroid hyperplasia in rats with secondary hyperparathyroidism. PLoS One. 2020; 15(4): e0232428. PubMed Abstract | Publisher Full Text | Free Full Text Faculty Opinions Recommendation

59. Rodríguez-Ortiz ME, Pendón-Ruiz de Mier MV, Rodríguez M: Parathyroidectomy in dialysis patients: Indications, methods, and consequences. Semin Dial. 2019; 32(5): 444-51.

PubMed Abstract | Publisher Full Text

60. Ma L, Zhao S, Li Z: Effects of parathyroidectomy on bone metabolism in haemodialysis patients with secondary hyperparathyroidism. Scand J Clin Lab Invest. 2017; 77(7): 527-34.

PubMed Abstract | Publisher Full Text

61. Nvan der Plas WY, Dulfer RR, Koh EY, et al.: Safety and efficacy of subtotal or total parathyroidectomy for patients with secondary or tertiary hyperparathyroidism in four academic centers in the Netherlands. Langenbecks Arch Surg. 2018; 403(8): 999-1005.

PubMed Abstract | Publisher Full Text | Free Full Text |

Faculty Opinions Recommendation

62. Z Zhang Y, Lu Y, Feng S, et al.: Evaluation of laboratory parameters and symptoms after parathyroidectomy in dialysis patients with secondary hyperparathyroidism. Ren Fail. 2019; 41(1): 921-9. PubMed Abstract | Publisher Full Text | Free Full Text Faculty Opinions Recommendation

63. Ivarsson KM, Akaberi S, Isaksson E, et al.: Cardiovascular and Cerebrovascular Events After Parathyroidectomy in Patients on Renal Replacement Therapy. World J Surg. 2019; 43(8): 1981-8. PubMed Abstract | Publisher Full Text | Faculty Opinions Recommendation

64. Komaba H, Taniguchi M, Wada A, et al.: Parathyroidectomy and survival among Japanese hemodialysis patients with secondary hyperparathyroidism. Kidney Int. 2015; 88(2): 350-9. PubMed Abstract | Publisher Full Text

65. Chen L, Wang K, Yu S, et al.: Long-term mortality after parathyroidectomy among chronic kidney disease patients with secondary hyperparathyroidism: A systematic review and meta-analysis. Ren Fail. 2016; 38(7): 1050-8.

PubMed Abstract | Publisher Full Text

66. Pattou FN, Pellissier LC, Noël C, et al.: Supernumerary parathyroid glands: Frequency and surgical significance in treatment of renal hyperparathyroidism. World J Surg. 2000; 24(11): 1330-4. PubMed Abstract | Publisher Full Text

67. N Ge Y, Yang G, Wang N, et al.: Bone metabolism markers and hungry bone syndrome after parathyroidectomy in dialysis patients with secondary hyperparathyroidism. Int Urol Nephrol. 2019; 51(8): 1443-9. PubMed Abstract | Publisher Full Text | Faculty Opinions Recommendation 


\section{Open Peer Review}

\section{Current Peer Review Status:}

\section{Editorial Note on the Review Process}

Faculty Reviews are review articles written by the prestigious Members of Faculty Opinions. The articles are commissioned and peer reviewed before publication to ensure that the final, published version is comprehensive and accessible. The reviewers who approved the final version are listed with their names and affiliations.

\section{The reviewers who approved this article are:}

\section{Version 1}

\section{Masafumi Fukagawa}

Division of Nephrology, Endocrinology and Metabolism, Tokai University School of Medicine, Kanagawa, Japan

Competing Interests: No competing interests were disclosed.

\section{Geoffrey A. Block}

1 U.S. Renal Care, Plano, TX, USA

2 Reata Pharmaceuticals, Dallas, TX, USA

Competing Interests: No competing interests were disclosed.

\section{Tadao Akizawa}

Division of Nephrology, Department of Medicine, Showa University School of Medicine, Tokyo, Japan

Competing Interests: No competing interests were disclosed.

The benefits of publishing with F1000Research:

- Your article is published within days, with no editorial bias

- You can publish traditional articles, null/negative results, case reports, data notes and more

- The peer review process is transparent and collaborative

- Your article is indexed in PubMed after passing peer review

- Dedicated customer support at every stage

For pre-submission enquiries, contact research@f1000.com 